\title{
Analysis of the Role of Bradysia impatiens (Diptera: Sciaridae) as a Vector Transmitting Peanut Stunt Virus on the Model Plant Nicotiana benthamiana
}

\author{
Marta Budziszewska, Patryk Frąckowiak (1) and Aleksandra Obrępalska-Stęplowska *(D)
}

check for updates

Citation: Budziszewska, M.; Frąckowiak, P.;

Obrępalska-Stẹplowska, A. Analysis of the Role of Bradysia impatiens (Diptera: Sciaridae) as a Vector Transmitting Peanut Stunt Virus on the Model Plant Nicotiana benthamiana Cells 2021, 10, 1546. https://doi.org/ 10.3390/cells10061546

Academic Editors: Henryk

Hanokh Czosnek and Ahmed Hadidi

Received: 20 March 2021

Accepted: 17 June 2021

Published: 18 June 2021

Publisher's Note: MDPI stays neutral with regard to jurisdictional claims in published maps and institutional affiliations.

Copyright: (C) 2021 by the authors. Licensee MDPI, Basel, Switzerland. This article is an open access article distributed under the terms and conditions of the Creative Commons Attribution (CC BY) license (https:// creativecommons.org/licenses/by/ $4.0 /)$.

\author{
Department of Molecular Biology and Biotechnology, Institute of Plant Protection-National Research Institute, \\ Władysława Węgorka 20, 60-318 Poznań, Poland; m.budziszewska@iorpib.poznan.pl (M.B.); \\ p.frackowiak@iorpib.poznan.pl (P.F.) \\ * Correspondence: ao.steplowska@iorpib.poznan.pl or olaob@o2.pl
}

\begin{abstract}
Bradysia species, commonly known as fungus gnats, are ubiquitous in greenhouses, nurseries of horticultural plants, and commercial mushroom houses, causing significant economic losses. Moreover, the insects from the Bradysia genus have a well-documented role in plant pathogenic fungi transmission. Here, a study on the potential of Bradysia impatiens to acquire and transmit the peanut stunt virus (PSV) from plant to plant was undertaken. Four-day-old larvae of B. impatiens were exposed to PSV-P strain by feeding on virus-infected leaves of Nicotiana benthamiana and then transferred to healthy plants in laboratory conditions. Using the reverse transcription-polymerase chain reaction (RT-PCR), real-time PCR (RT-qPCR), and digital droplet PCR (RT-ddPCR), the PSV RNAs in the larva, pupa, and imago of B. impatiens were detected and quantified. The presence of PSV genomic RNA strands as well as viral coat protein in N. benthamiana, on which the viruliferous larvae were feeding, was also confirmed at the molecular level, even though the characteristic symptoms of PSV infection were not observed. The results have shown that larvae of B. impatiens could acquire the virus and transmit it to healthy plants. Moreover, it has been proven that PSV might persist in the insect body transstadially. Although the molecular mechanisms of virion acquisition and retention during insect development need further studies, this is the first report on B. impatiens playing a potential role in plant virus transmission.
\end{abstract}

Keywords: virus transmission; cucumovirus; fungus gnat; plant-insect-virus interactions; virus detection; virus vector

\section{Introduction}

Bradysia species, commonly referred to as mushrooms fly, nuisance fly, black fungus gnat, or dark-winged fungus gnat, belong to the Sciaridae family and are considered to be harmful in greenhouses [1]. These insects are especially ubiquitous in nurseries of horticultural plants, such as cucumber, tomatoes, ornamental plants productions, and edible mushrooms, causing significant damages and thus economic loss. Sciarid larvae are known to be polyphagous. Primarily, they feed on algae, fungi, decomposed plant debris, but they have also been reported to attack healthy plants (i.e., seedlings of carnations, cucumber, as well field plants like soybean, wheat, corn, pea) by feeding on roots and stems of young seedlings [2-5], or occasionally on leaf tissues and cuttings [5,6].

The life cycle of Bradysia spp. lasts 15-49 days, depending on the environmental conditions, and includes eggs, four larval instars, the pupal stage, and imagoes [7]. Adult females deposit eggs usually very close to the stem of young plants $[3,8]$, which may be of importance for possible pathogen transmission. Herbivorous larvae cause physical damages to the stem and root tissues, disturbing water and nutrients uptake, which, in consequence, leads to wilting, stunting [3], chlorosis, premature foliage loss, or eventually, death $[9,10]$. Larvae may also affect plants indirectly, by allowing the entry of soil-borne 
pathogens. Notably, fungus gnats are known to be vectors of fungal pathogens. The role of Bradysia genus representatives in the transmission of oomycete and fungi, such as Pythium spp., Fusarium spp., and Verticillium spp., is well documented [11-15]. In 2017, Park et al. characterized the microbes of B. agrestis, indicating that this insect was associated with fungal and bacterial species. The dominant genera were Bacillus, Rhodococcus, and Pseudomonas, but only the latter might be dangerous for the agricultural environments in favourable conditions [16].

The viral gene expression data, obtained in our previous experiments on N. benthamiana-virus interactions, indicated the PSV genes were detectable in some healthy plants (non-infected), suggesting accidental transmission of the virus from infected plants to remote healthy plants growing inside the same cabin. The only factor that might have contributed to these infections were insects of $B$. impatiens, incidentally brought to strictly controlled glasshouse cabins, most probably with the soil. In the absence of other potential vectors, we hypothesized that these insects might be the agents transmitting the viral pathogen to healthy plants.

Peanut stunt virus (PSV) belongs to the Cucumovirus genus in the family Bromoviridae. It is a severe pathogen distributed worldwide with a broad host range, mainly of legumes such as pea (Pisum sativum L.), bean (Phaseolus vulgaris L.), and yellow lupine (Lupinus luteus L.) [17]. Its genome ( $~ 8.3 \mathrm{~kb}$ in size) consists of three genomic positive-sense singlestranded RNAs and two subgenomic RNAs. RNA1 and 2 encode proteins $1 \mathrm{a}$ and 2a, respectively, which are components of the viral replication complex. RNA 3 encodes protein $3 a$, which is involved in the virus movement. Subgenomic RNA4 acts as a messenger RNA for the viral coat protein (CP), whereas RNA4A encodes protein $2 b$, known as the post-transcriptional gene silencing (PTGS) suppressor [18]. Some of the PSV strains, including the one used in our study, PSV-P, contain satellite RNA [19]. In the experimental conditions, PSV is mechanically transmissible via the plant sap. In contrast, in the field, it is known to be transmitted in a non-persistent manner by several aphid species and mechanically $[14,17,20]$.

This study is aimed at verification of the hypothesis of the potential involvement of $B$. impatiens in the transmission of PSV. Using the two highly sensitive molecular biology tools, RT-qPCR, and RT-ddPCR, and a biological test based on the plant inoculation method, we have undertaken a study on the possibility of the virus acquisition by B. impatiens. Then, we explored PSV retention in the body of particular insect's developmental stages and its further transmission to healthy plants.

The results have shown that $B$. impatiens might be considered as a vector of not only fungal phytopathogens, but also plant RNA viruses.

\section{Materials and Methods}

\subsection{Virus-Free Insect Cultivation}

For experimental purposes, the colony of $B$. impatiens originating from the slugs breeding was kindly provided by the Department of Entomology and Agricultural Pests, Institute of Plant Protection-NRI (Poznań, Poland). The larvae, pupae, and adults were cultivated in moist soil, in a 1-L plastic box with a perforated lid for ventilation. Larvae were fed on Chinese cabbage leaves or carrot roots. In the next step, 20 adult fungus gnats were collected by exhauster aspiration and placed on a Petri dish with $2 \%(w / v)$ agar medium, at room temperature, in the laboratory conditions. The females laid eggs, of which 100-150 were taken and applied directly to a fresh $2 \%(w / v)$ agar plate with a small brush. To confirm that insect material is PSV-free, the 3-day-old eggs (10 eggs/sample) were taken with a brush and placed in an Eppendorf tube, washed with sterile water, and stored in $70 \%$ ethanol at $-80{ }^{\circ} \mathrm{C}$ for further RT-PCR detection with virus-specific primers (Table 1 ). Once the remaining eggs had hatched, the 2-3 second-instar larvae (about 4-day-old), and subsequently 2-3 3-day-old pupae and 2-3 adult insects were also collected with small brush and exhauster (for adults) and placed into Eppendorf tubes, as mentioned above, for RT-PCR tests. 


\subsection{The Insect Species Identification Using PCR}

The taxonomic identification of cultivated fungus gnats belonging to the Bradysia genus was based on the sequence analysis of the I subunit of mitochondrial cytochrome c oxidase gene ( $m t C O I)$. For this purpose, the DNA was isolated from six samples, each containing a single adult insect, using a NucleoSpin Tissue Kit (Macharey-Nagel, Dueren Germany) followed by PCR reaction with primers, designed by Folmer et al. [20], and hybridizing to the fragment of $m t C O I$ gene. PCR profiles were as follows: denaturation at $95{ }^{\circ} \mathrm{C}$ for $3 \mathrm{~min}, 35$ cycles: $95{ }^{\circ} \mathrm{C}$ for $30 \mathrm{~s}, 45^{\circ} \mathrm{C}$ for $30 \mathrm{~s}, 72{ }^{\circ} \mathrm{C}$ for $40 \mathrm{~s}$, and final elongation at $72{ }^{\circ} \mathrm{C}$ for $5 \mathrm{~min}$. Products of amplification were sequenced and submitted to the GenBank database with the following accession numbers MW798234, MW798235, MW798236, MW798237, MW798238, MW798239. The obtained results were analysed using the Nucleotide BLAST tool (https:/ / blast.ncbi.nlm.nih.gov/Blast.cgi. The National Center for Biotechnology Information, NCBI, Bethesda, MD, USA).

\subsection{Viral Strain and Plant Material}

As a viral source, the peanut stunt virus strain P (PSV-P, from Lupinus luteus L.) from our laboratory collection was used [19]. PSV was maintained and propagated in Pisum sativum. To prepare inoculum for mechanical transmission, the infected pea plants, showing systemic symptoms, were homogenized in $0.05 \mathrm{M}$ phosphate buffer, $\mathrm{pH} 7.5$, and the sap was rubbed in the previously carborundum-dusted leaves of 3-4-week-old $N$. benthamiana seedlings [17]. The plants were grown in the greenhouse with a $16 \mathrm{~h}$ light $/ 8 \mathrm{~h}$ dark cycle at $21 / 18{ }^{\circ} \mathrm{C}$ day/night temperature. Plants were observed for symptom development for 2-4 weeks after mechanical inoculation. After 10-14 days, the presence of PSV RNAs was verified in the systemic leaves by RT-PCR with specific primers (Table 1). Infected plants were used as a virus source for the transmission studies by fungus gnats. All biological experiments were conducted in the glasshouse of the Department of Molecular Biology and Biotechnology of the Institute of Plant Protection-National Research Institute (Poznań, Poland).

\subsection{Studies on the Fungus Gnats Ability to Acquire a Virus}

To analyse the potential of the fungus gnat to acquire the virus, we collected 30-40 larvae from a virus-free colony of $B$. impatiens (4-day-old) and placed them for $24 \mathrm{~h}$, on a sterile Petri dish with $2 \%(w / v)$ agar medium and leaf disks of PSV-infected $N$. benthamiana plants, as a food source. In negative controls, $30-40$ specimens of virus-free larvae were placed for $24 \mathrm{~h}$ on a separate Petri dish, with agar and disks of a healthy N. benthamiana (Figure 1). After this time, virus-exposed and non-exposed larvae were transferred separately to sterile plates with $2 \%(w / v)$ agar, according to Gardiner et al. [21], for the next $24 \mathrm{~h}$. Then, 2-3 larvae of B. impatiens, PSV-exposed and non-exposed, were caught with a brush and put respectively in Eppendorf tubes with $70 \%$ ethanol and frozen at $-80^{\circ} \mathrm{C}$, for further RT-PCR reactions with PSV-specific primers (Table 1). To verify the possibility of virus persistence at the insect's developmental stages, 3-day-old pupae (2-3 specimens), and emerging adults (2-3 individuals), developed from virus-exposed and respectively virus-free larvae were collected. RT-PCR detection of PSV was subsequently performed. Additionally, the PSV detection and quantification analyses of viral RNAs in the single larva, pupa, and imago (from PSV-exposed and non-exposed specimens) were also conducted. For this purpose, 4-5 specimens of 4-day-old larvae, 3-day-old pupae, and newly emerged imago were caught and put individually in Eppendorf tubes for quantitative analyses using the digital droplet PCR (ddPCR) approach preceded by RT-qPCR-based virus detection. A virus acquisition study was performed in triplicate.

\subsection{Virus Transmission Assay}

After the acquisition access period (AAP), the virus-exposed larvae were transferred to a new, sterile Petri dish for $24 \mathrm{~h}$ [21], as was described above. Then, 5-7 randomly collected larvae were placed in a soil pot (a soil used in all biological tests was previously 
heat sterilised at $100-120^{\circ} \mathrm{C}$ ) near to the root of two-leaf stage $N$. benthamiana healthy seedlings, previously molecularly tested to exclude PSV infection. As negative controls, we used larvae feeding on healthy leaf disks and proceeded as described above. The analysis included five biological replicates.

Table 1. The sequences of diagnostic primers hybridizing to peanut stunt virus RNAs.

\begin{tabular}{|c|c|c|c|c|}
\hline $\begin{array}{l}\text { Genomic } \\
\text { Strand }\end{array}$ & Primer & Sequence $5^{\prime}>3^{\prime}$ & & $\begin{array}{c}\text { Amplicon Length, } \\
\text { Annealing } \\
\text { Temperature } \\
\text { Ta }{ }^{\circ} \mathrm{C}\end{array}$ \\
\hline \multirow{4}{*}{ RNA1 } & P1a & CACAAATCCGGCTGAGAAATG & \multirow{2}{*}{ this study } & \multirow{2}{*}{$\begin{array}{l}426 \mathrm{bp} \\
57.3\end{array}$} \\
\hline & $\mathrm{P} 1 \mathrm{~b}$ & CAAGATACCAGCGTAGATCAC & & \\
\hline & $\mathrm{q} 1 \mathrm{~F}$ & CTTCTGCCCTCGTTGATAAAG & \multirow{2}{*}{ [22] } & \multirow{2}{*}{$\begin{array}{l}131 \mathrm{bp}, \\
57\end{array}$} \\
\hline & q1R & CATACCGATTTCGAATCACTTC & & \\
\hline \multirow{4}{*}{ RNA2 } & $\mathrm{v} 2 \mathrm{~b} 1$ & $\begin{array}{c}\text { TGAGAATTCAAAAAAAAAACAATGTCGAG } \\
\text { TGTCGAGCAG }\end{array}$ & \multirow{2}{*}{ this study } & \multirow{2}{*}{$\begin{array}{l}320 \mathrm{bp}, \\
59\end{array}$} \\
\hline & $\mathrm{v} 2 \mathrm{~b} 2$ & CGCCTGCAGTTATCAGGAATAACTACCCTC & & \\
\hline & $\mathrm{q} 2 \mathrm{aF}$ & CTTCTAGGTATCCCCGTAAG & \multirow{2}{*}{ [22] } & \multirow{2}{*}{$\begin{array}{l}130 \mathrm{bp}, \\
56\end{array}$} \\
\hline & $\mathrm{q} 2 \mathrm{aR}$ & CAAGCACATTGATACCCTATC & & \\
\hline \multirow{4}{*}{ RNA3 } & P3MPCP1 & GAGGTATGGTTATCTTGGACATC & \multirow{2}{*}{ [19] } & \multirow{2}{*}{$\begin{array}{l}958 \mathrm{bp}, \\
60\end{array}$} \\
\hline & P3МРCP2 & GAAGTTGAACACAGGAAACCTTC & & \\
\hline & qCP F & ACACATACACTTCGTTGGATG & \multirow{2}{*}{ [22] } & \multirow{2}{*}{$\begin{array}{l}130 \mathrm{bp}, \\
56\end{array}$} \\
\hline & qCP R & CCTCWTCTTCGGAAATTCAG & & \\
\hline
\end{tabular}

The plants were kept in insect-rearing cages (BugDorm, Taichung, Taiwan) under controlled conditions, as was mentioned above. Three weeks post-inoculation, two leaf disks were collected from all tested plants, and the total RNA was isolated. Afterward, the virus RT-PCR detection followed by real-time PCR and ddPCR were performed (Figure 1).

\subsection{Total RNA Isolation}

Total RNA was isolated from virus-exposed or non-exposed insect samples and small two leaf disks (about $25 \mathrm{mg}$ ) of all tested $\mathrm{N}$. benthamiana plants. Plant material, as well as whole insect body samples, were homogenized with a small plastic pestle. RNA isolation was carried out using a Tri-Reagent solution (Ambion, Life Technologies, Naugatuck, CT, USA), followed by 2-propanol precipitation. Total RNA from insect body and plant material was dissolved, respectively, in $10 \mu \mathrm{L}$ and $20 \mu \mathrm{L}$ of RNase-free water. The RNA quantity was assessed with spectrophotometer NanoDrop ND-1000 (Thermo Scientific, Lenexa, KS, USA) and analysed under non-denaturing conditions by electrophoresis. Aliquots were stored at $-80^{\circ} \mathrm{C}$ until use.

\section{7. $R T-P C R$}

For the reverse transcription step, $0.5 \mu \mathrm{g}$ of total RNA from individual insect, $1 \mu \mathrm{g}$ of total RNA from remaining insect samples, and $1 \mu \mathrm{g}$ from plant tissue were combined with $200 \mathrm{ng}$ of random hexamer primers and incubated at $65^{\circ} \mathrm{C}$ for $5 \mathrm{~min}$. Afterward, the mixture was cooled on ice and $4 \mu \mathrm{L}$ of $5 X$ Reaction Buffer, $2 \mu \mathrm{L}$ of $10 \mathrm{mM}$ dNTPs, $20 \mathrm{U} / \mu \mathrm{L}$ RiboLock RNase Inhibitor and $200 \mathrm{U} / \mu \mathrm{L}$ of RevertAid M-MuLV Reverse Transcriptase (Thermo Scientific, Lenexa, KS, USA) were added. The reaction was carried out in a total volume of $20 \mu \mathrm{L}$. The thermal profile was as follows: $10 \mathrm{~min}$ at $25^{\circ} \mathrm{C}, 60 \mathrm{~min}$ at $42{ }^{\circ} \mathrm{C}$, termination at $70{ }^{\circ} \mathrm{C}$ for $5 \mathrm{~min}$. In the case of insects, the synthesized cDNAs were additionally amplified using PCR with $m t C O I$ specific primers using above mentioned thermal conditions. The obtained cDNA served also as a template for PCR reactions with 
primers amplifying three PSV genes: $1 \mathrm{a}, 2 \mathrm{~b}$ as well the fragment spanning the movement and coat protein (MPCP) (Table 1). PCR was performed in $15 \mu \mathrm{L}$ of the reaction mixture that contained 1X DreamTaq Master mix (ThermoScientific, Lenexa, KS, USA), $0.5 \mu \mathrm{M}$ primers, $1 \mu \mathrm{L}$ of cDNA template (reverse transcribed on the total RNA isolated from 2-3 individuals) and sterile water to the final volume. Thermal profiles consisted of initial denaturation at $95^{\circ} \mathrm{C}$ for $3 \mathrm{~min}$ followed by 40 cycles of denaturation at $95^{\circ} \mathrm{C}$ for $30 \mathrm{~s}$, annealing step at a temperature appropriate for used primer pairs (Table 1) for $30 \mathrm{~s}$, elongation at $72{ }^{\circ} \mathrm{C}$ for $40 \mathrm{~s}$, and final extension at $72{ }^{\circ} \mathrm{C}$ for $5 \mathrm{~min}$. As positive controls, we used $1 \mu \mathrm{L}$ of cDNA synthesized from $1 \mu \mathrm{g}$ of total RNA isolated from the virus-infected $N$. benthamiana plant. The RT-PCR was electrophoretically analysed, and products of randomly chosen plant and insect samples were extracted from the gel using The Wizard ${ }^{\circledR}$ SV Gel and PCR Clean-Up System (Promega, Madison, WI, USA). RT-PCR products were Sanger sequenced (Genomed S.A., Warsaw, Poland) and then analysed in the Nucleotide BLAST tool.

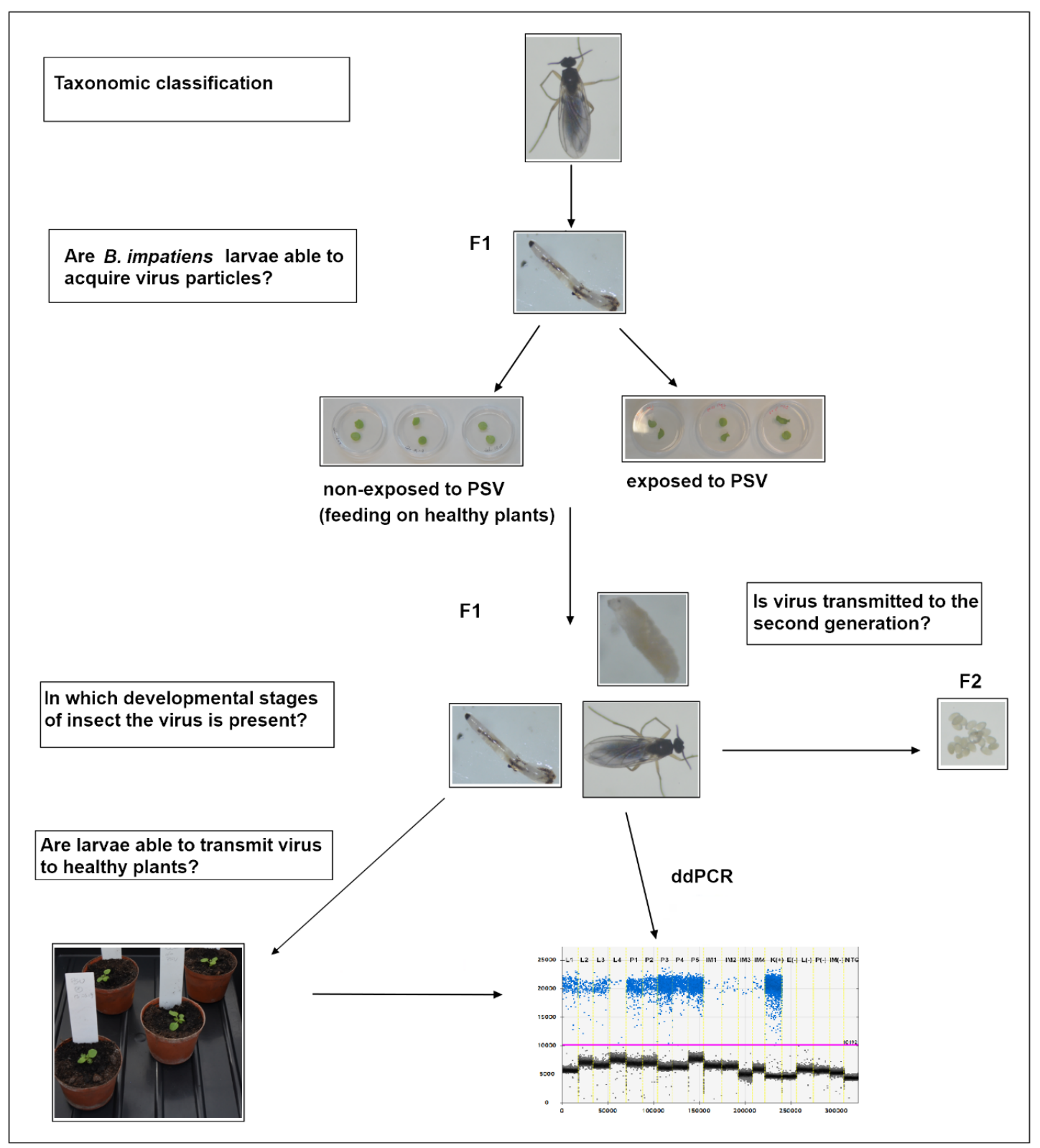

Figure 1. The scheme of experimental setup designed to analyse the B. impatiens larvae's ability to acquire a virus, virus transstadial persistence, and the potential to spread the virus to healthy plants. 


\subsection{Virus Detection in Insect Individuals Using Real-Time PCR}

The reaction was carried out in the $10 \mu \mathrm{L}$ of reaction mixture containing $1 \mathrm{X}$ iTaq Universal SYBR Green Supermix (Bio-Rad, Hercules, CA, USA), $0.3 \mu \mathrm{M}$ each reverse and forward primers $\mathrm{q} 1 \mathrm{~F} / \mathrm{q} 1 \mathrm{R}, \mathrm{q} 2 \mathrm{aF} / \mathrm{q} 2 \mathrm{aR}, \mathrm{qCPF} / \mathrm{qCPR}$ complementary, respectively, to the PSV 1a, $2 \mathrm{a}$ and CP gene (Table 1), $1 \mu \mathrm{L}$ of cDNA template (transcribed on total RNA isolated from tested individual larva, pupa, imago, healthy and PSV-infected N. benthamiana), and the sterile water. The amplification was performed in a LightCycler 96 real-time thermocycler (Roche Applied Science, Mannheim, Germany) under the following cycling conditions: $95^{\circ} \mathrm{C}$ for $3 \mathrm{~min}$, followed by 40 cycles of $95^{\circ} \mathrm{C}$ for $15 \mathrm{~s}, 55^{\circ} \mathrm{C}$ for $30 \mathrm{~s}$ (Table 1) and $72{ }^{\circ} \mathrm{C}$ for $30 \mathrm{~s}$. All samples were analysed in three technical replicates.

\subsection{Quantitative Analysis of Viral RNAs Using Digital Droplet PCR (RT-ddPCR)}

The digital droplet PCR (ddPCR) technique has provided an alternative method for absolute quantitation of nucleic acids based on fractionating each sample into water-oil emulsion before the PCR reaction that occurs within each droplet. The copy number of viral targets can be assessed by direct counting PCR-positive droplets among all reactions according to Poisson's distribution. The reactions were performed using BioRad QX200 System (Bio-Rad, Hercules, CA, USA). The reaction mixture contained 1X QX200 ddPCR EvaGreen Supermix (Bio-Rad, Hercules, CA, USA), $0.25 \mu \mathrm{M}$ of PSV specific primer mix (q1F/q1R, q2aF/q2aR) (Table 1), $1 \mu \mathrm{L}$ of previously synthesized cDNA, and sterile water to a final volume of $20 \mu \mathrm{L}$. The cDNA of positive control was diluted $1 \times 10^{-4}-10^{-6}$ (PSVinoculated N. benthamiana). Vortexed samples were loaded into DG8 ${ }^{\mathrm{TM}}$ Cartridge for QX200 Droplet Generation (Bio-Rad) sample wells, and $70 \mu \mathrm{L}$ of QX200 Droplet Generation Oil for Eva Green (Bio-Rad) was added into oil wells. The reaction mixture was then emulsified with Droplet Generation Oil for EvaGreen (Bio-Rad, Hercules CA, USA). Afterward, the prepared emulsions were carefully transferred into a 96-well plate, heat-sealed using a

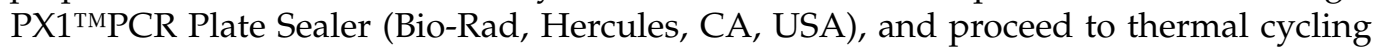
using C1000 Thermal Cycler (Bio-Rad). The thermal conditions were as follows: an initial denaturation cycle of $10 \mathrm{~min}$ at $95^{\circ} \mathrm{C}$, followed by 40 cycles of denaturation for $30 \mathrm{~s}$ at $94^{\circ} \mathrm{C}$, annealing for $60 \mathrm{~s}$ at $57^{\circ} \mathrm{C}$ (ramping rate set to $2^{\circ} \mathrm{C} / \mathrm{s}$ ), and a final incubation for $10 \mathrm{~min}$ at $98^{\circ} \mathrm{C}$, ending at $4{ }^{\circ} \mathrm{C}$. After amplification, the 96 -well plate was placed into the Droplet Reader (Bio-Rad, Hercules, CA, USA). The reader measured the intensity of green fluoresce signals of each droplet and proceeded with the QuantaSoft ${ }^{\mathrm{TM}}$ analysis software version 1.7 (Bio-Rad). Positive droplets with higher fluorescent signals and negative droplets with lower fluorescent signals were divided by applying a fluorescence amplitude threshold. The absolute concentration of each sample was automatically reported by the ddPCR software by calculating the ratio of the positive droplets over the total droplets combined with Poisson distribution https:/ / www.bio-rad.com/webroot/web/pdf/lsr/literature/ Bulletin_6407.pdf. Thus, the final concentration of templates was equal to the results, as calculated by the software.

\subsection{Western Blot Assay}

Immunodetection of PSV coat protein in N. benthamiana plants was performed using Western blot analysis after the plant exposure to the virus-infected larvae of $B$. impatiens. Seven days after the contact with viruliferous larvae, one disc of the systemic leaf from each plant was taken. As a negative control, we used plant material from the healthy, untreated $N$. benthamiana. As a positive control, we used a leaf disc from N. benthamiana mechanically inoculated with PSV, as well as the two samples of purified particles of PSV-P from our collection. The tested plant samples were homogenized in $100 \mu \mathrm{L} 2 \mathrm{X}$ Laemmli sample buffer. Two microliters of virus preparation were mixed with $8 \mu \mathrm{L}$ of sterile water and $10 \mu \mathrm{L}$ of $2 \mathrm{X}$ sample buffer. Then, all samples were denatured at $99^{\circ} \mathrm{C}$ for $10 \mathrm{~min}$, centrifuged at $16,500 \times g$ for $10 \mathrm{~min}$ to remove plant debris. The PSV CP protein was detected by Western blotting as follows: $15 \mu \mathrm{L}$ of the protein lysates were separated in $12 \%$ sodium dodecyl sulphate-polyacrylamide gel electrophoresis (SDS-PAGE), followed by protein transfer 
onto a PVDF membrane. The filter was blocked for $1 \mathrm{~h}$ at room temperature with $5 \%$ non-fat milk in Tris-buffered saline with $0.1 \%$ Tween (TBS-T), followed by incubation ( $1 \mathrm{~h}$ at room temperature) with antiserum against native PSV virion preparations (produced in rabbit) (kindly provided by Prof. H. Pospieszny from The Department of Virology and Bacteriology of IPP-NRI, Poznań, Poland) at a dilution of 1:1000 in blocking buffer. The membrane was washed three times with TBS-T, followed by incubation ( $1 \mathrm{~h}$ at room temperature) with a secondary antibody conjugated with phosphate alkaline (goat antirabbit IgG, Sigma-Aldrich, Darmstadt, Germany) at a dilution of 1:25,000. Afterward, the membrane was washed three times with TBS-T and the reaction was developed with $1 \mathrm{~mL}$ of Western Blue ${ }^{\circledR}$ Stabilized Substrate for Alkaline Phosphatase (Promega, Madison, WI, USA).

\section{Results}

\subsection{Insect Taxonomic Classification}

The species of a cultivated population of fungus gnats were analysed based on the DNA sequence of the $m t C O I$ gene. The amplified and subsequently sequenced $681 \mathrm{bp}$ fragments of the mtCOI gene of the fungus gnats were compared with Bradysia sequences already deposited in the GenBank database and showed $99-100 \%$ of nucleotide sequence identity to Bradysia impatiens species, also known as B. difformis or B. paupera [23].

\subsection{PSV Acquisition by B. impatiens Larvae}

The exposure of $B$. impatiens larvae to PSV-infected plant tissue, followed by the RTPCR test, confirmed the presence of PSV in fungus gnat's body. Therefore, the possibility of PSV persistence in the subsequent insect developmental stages was also molecularly tested. The specific RT-PCR amplification products for viral genes $1 a, 2 b$, and MPCP segment of respective size 426, 320, 958 bp were obtained in PSV-exposed larvae, and no products were observed in larvae not-exposed to the virus (Figure 2). The analysis of the virus persistence in the following developmental stages showed that both pupae and imago samples of B. impatiens maintained PSV as well, while in insects without previous contact with the virus (negative controls), the viral RNA was undetectable (Figure 2). Additionally, using the RT-PCR, we detected the specific products of the 1a PSV gene in the total RNA isolated from the second generation (F2) of eggs of B. impatiens (Figure S1). However, because there was no repeatability, this data remained inconclusive. Chosen amplicons of $1 a, 2 b$, and MPCP region obtained for virus-exposed insects were Sanger sequenced. The nucleotide sequence analyses using BLAST revealed their high nucleotide sequence identity in the range of $98.5-99.2 \%, 99.66-100 \%$, and $99.2-100 \%$, to corresponding PSV-P RNAs, previously deposited in the GenBank (NCBI, Bethesda, MD, USA) under accession numbers EU570236 (RNA1), EU570237 (RNA2), and EU570238 (RNA3), respectively.

\subsection{Analysis of Virus RNA Accumulation in Individuals of Fungus Gnats at Various Developmental Stages}

The virus was detected in two successive developmental stages of B. impatiens obtained from larvae previously exposed to PSV-infected plants. No amplification products were obtained for the control B. impatiens specimens fed on healthy plants. The melting peaks of the amplified fragment of the PSV 1 a gene in the PSV-infected N. benthamiana (positive control) coincided with the dissociation curves of analysed insect samples exposed to PSV (Figure 3). The obtained Ct values for pupae reached the highest values between 24 and 27, in the case of larva from 27 to 28, whereas the $\mathrm{Ct}$ for imago individuals were registered between 30-33 (Figure 3). Quantitative analyses based on ddPCR indicated that the highest copy number of viral gene per $1 \mu \mathrm{L}$ of the reaction mixture was detected for pupae samples, a bit lower in the case of larvae, whereas in imago specimens, the level of virus RNA accumulation was the lowest in comparison to the remaining developmental stages (Figure 4). 


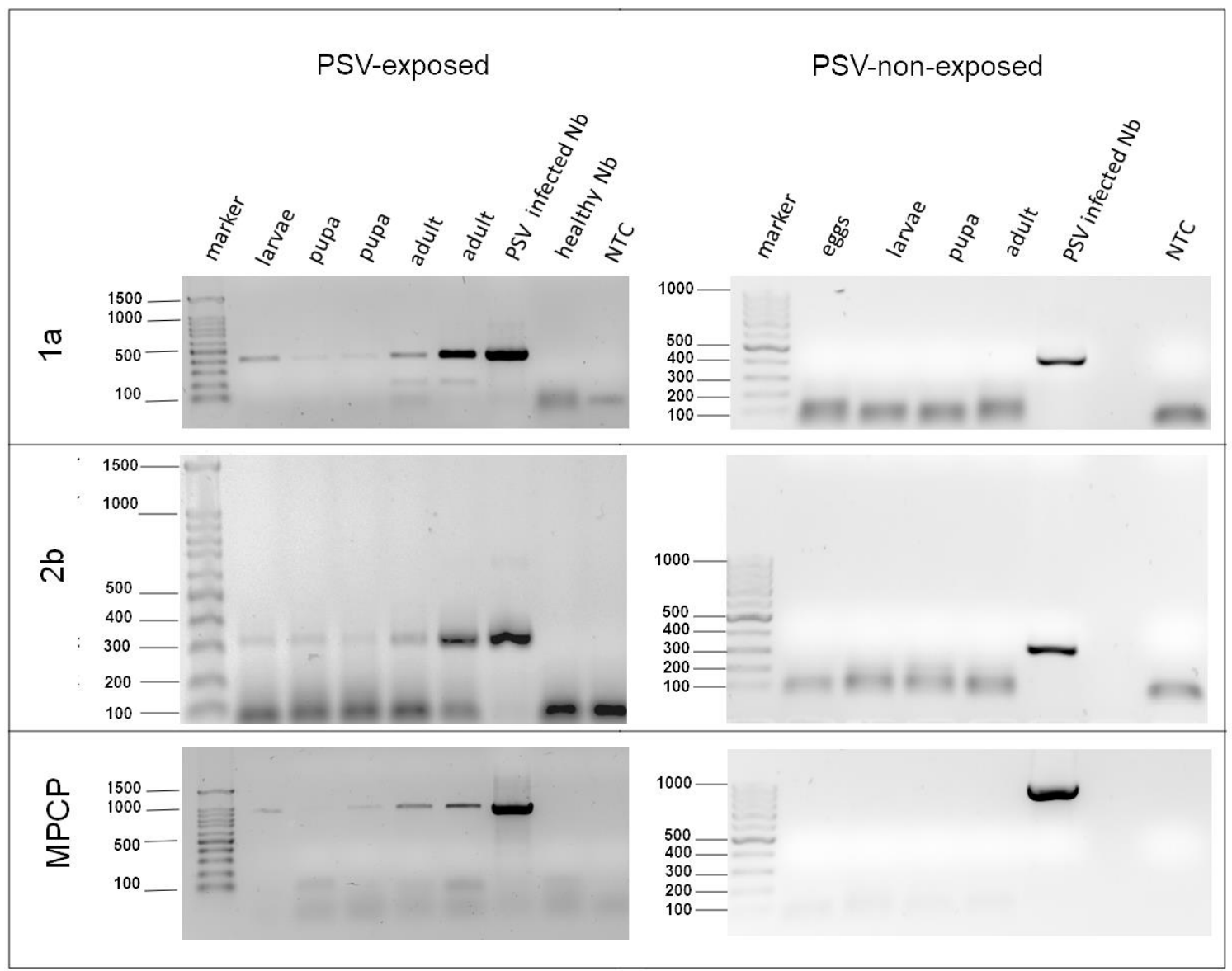

Figure 2. RT-PCR detection of peanut stunt virus RNAs in developmental stages of Bradysia impatiens. The RT-PCR products amplified with three PSV-specific primer pairs hybridizing to 1a, 2b, and fragment spanning 3a gene (movement protein, $\mathrm{MP}$ ) and coat protein (CP); total RNA isolated from larvae, pupae, and adults (2-3 specimens) of B. impatiens population cultivated in laboratory conditions on Petri dishes were used as a template. $\mathrm{M}$-marker Gene Ruler 100 bp (Thermo Scientific, Lenexa, KS, USA); NTC—no template control.

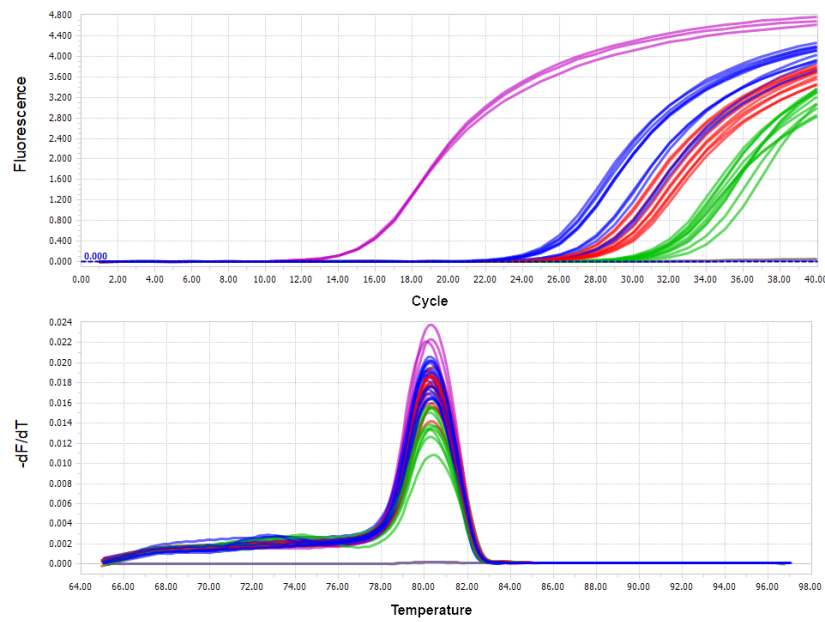

(a)

\begin{tabular}{|c|c|c|c|c|}
\hline & Sample & Ct value & echnica & plicates \\
\hline \multirow{4}{*}{ 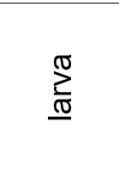 } & 1 & 27.28 & 27.73 & 27.35 \\
\hline & 2 & 28.61 & 28.94 & 28.81 \\
\hline & 3 & 28.43 & 28.09 & 28.39 \\
\hline & 4 & 28.37 & 28.45 & 28.71 \\
\hline \multirow{4}{*}{$\begin{array}{l}\text { 을 } \\
\text { 을 }\end{array}$} & 1 & 27.83 & 27.71 & 27.95 \\
\hline & 2 & 25.11 & 24.57 & 24.82 \\
\hline & 3 & 26.64 & 26.56 & 27.00 \\
\hline & 4 & 24.88 & 25.23 & 25.19 \\
\hline \multirow{4}{*}{ 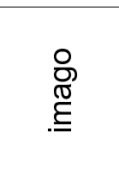 } & 1 & 31.07 & 31.91 & 32.00 \\
\hline & 2 & 32.83 & 32.64 & 33.22 \\
\hline & 3 & 30.82 & 31.34 & 31.06 \\
\hline & 4 & 31.16 & 31.43 & 31.25 \\
\hline $\mathrm{K}+\mathrm{PSV}$ & 1 & 14.82 & 14.66 & 14.77 \\
\hline
\end{tabular}

(b)

Figure 3. Results of PSV detection by RT-qPCR in single specimens of larva, pupa, and imago of B. impatiens after the virus acquisition by larvae feeding on PSV-infected N. benthamiana plants. Panel (a) The amplification plots of PSV 1a gene detected 
in a single larva—red line, pupa—blue line, imago—green line; positive control (PSV-infected N. benthamiana)—pink line (upper). Below, melting (dissociation) curves for amplicons of the PSV ORF 1a (replicase gene). For each developmental stage of fungus gnat, four single specimens were analysed, in three replicates. No amplification plots were obtained in the case of negative controls, including healthy larva, pupa, and imago, which were not exposed to PSV as well in NTC-no template control-grey line. Panel (b) Table with Ct values obtained by using in RT-qPCR analysis for PSV 1a gene for viruliferous larvae, pupae, and imago (four samples). Provided data concern the PSV-exposed larvae, pupae, and imago, which developed from PSV-exposed larvae, in three replicates. The Ct value for the positive control, the PSV-infected N. benthamiana (K + PSV), is also included.
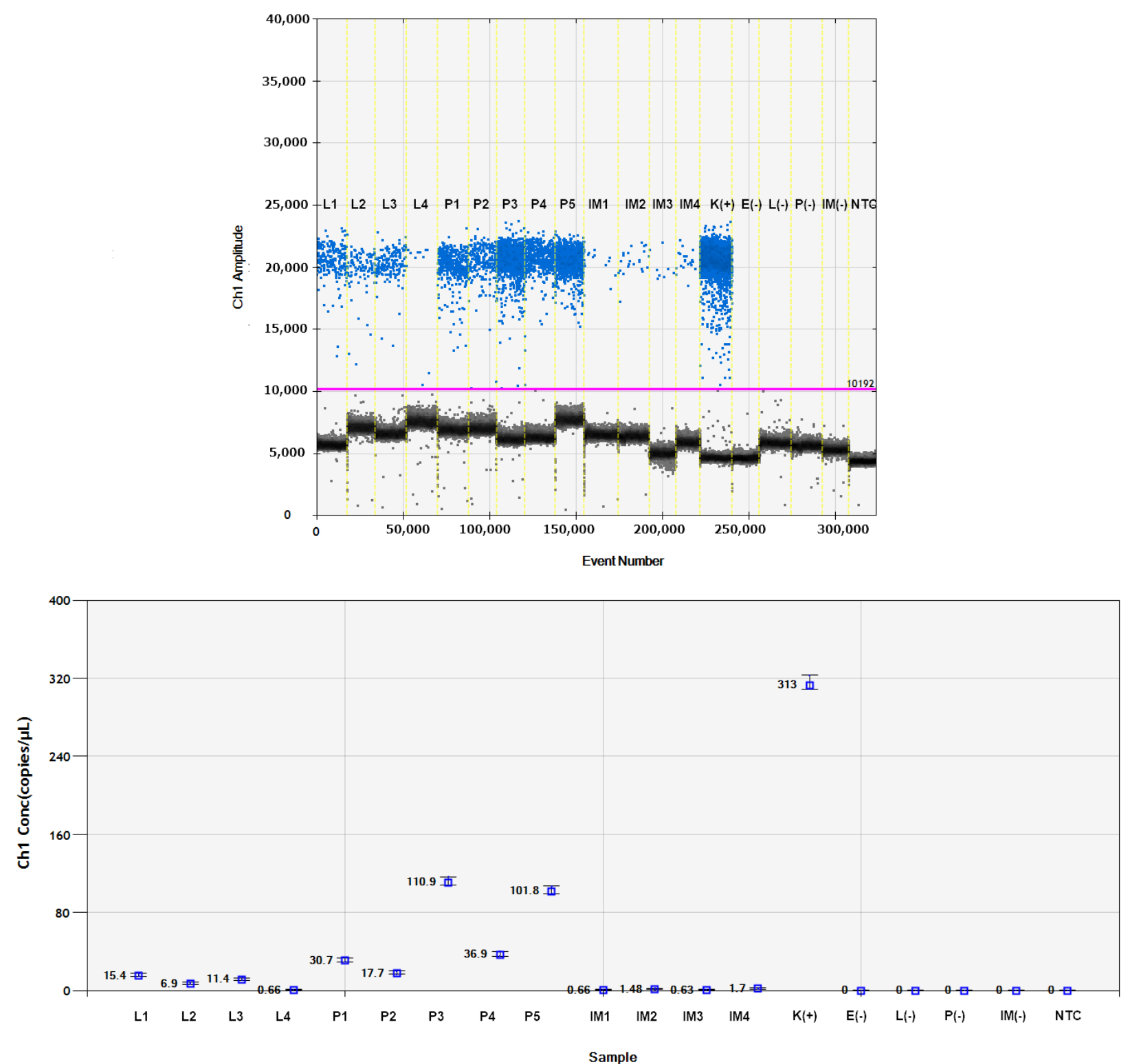

Figure 4. Detection of PSV 1a gene in the subsequent developmental stages of B. impatiens using EvaGreen digital droplet PCR approach. (Upper): 1-D plot diagram presents differences in amplitudes of fluorescence signals between positive and negative droplets. Blue dots: positive droplets with amplification, grey dots: negative droplets with no amplification. Pink line: threshold separating population of negative from positive droplets. (Below): the diagram showing the concentration of viral copies per $1 \mu \mathrm{L}$ of the reaction mixture. L-larva, $\mathrm{P}$ - pupa, IM-adult stage, E-egg from a virus-free B. impatiens colony, (-) —negative control samples: PSV-non-exposed, NTC—no template control, K(+) — positive control, N. benthamiana plants infected with PSV inoculum. 


\subsection{Bradysia impatiens Ability to Vector PSV to Healthy Plants}

To verify the virus vectoring ability of B. impatiens, the larvae which fed on PSVinoculated leaves and parallel on the virus-free plant were put into soil pots with young $N$. benthamiana. It is worth adding that, before the transmission assay, all plant seedlings were molecularly tested to exclude PSV infection.

The plant's visual inspection, three weeks after the inoculation by PSV-infected $B$. impatiens larvae, did not reveal any characteristic disease symptoms like chlorosis, mosaics, stunting, or leave malformations. Thus, they were tested for the presence of viral RNAs using molecular tools. PSV detection was performed utilizing RT-qPCR. The analyses were based on the amplification of three viral targets $1 a, 2 a$, and CP genes. The melting peaks of the amplified fragments for PSV-infected N. benthamiana (positive control) coincided with the dissociation curves obtained for tested $N$. benthamiana plants, previously treated with PSV-exposed B. impatiens larvae. No amplification plots were observed for healthy control plants (Figure 5).
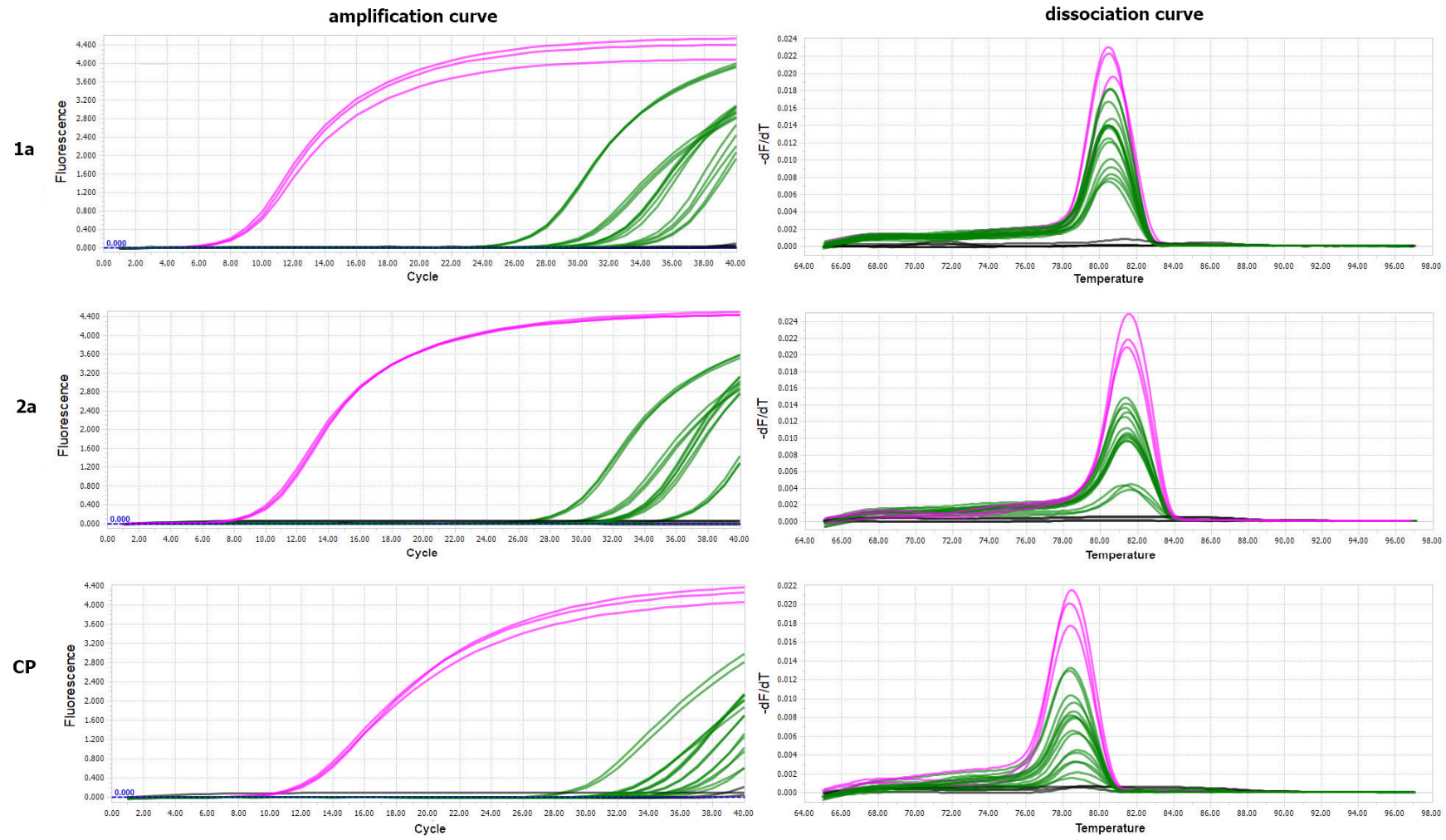

Figure 5. The RT-qPCR detection of PSV RNAs in N. benthamiana plants treated with PSV-exposed larvae of B. impatiens. The diagrams present the amplification (left) and dissociation curves (right) for amplification products of 1a, 2a, and CP PSV genes, detected in N. benthamiana plants; pink line-PSV-inoculated N. benthamiana (positive control); green lines-tested $N$. benthamiana plants treated with PSV-exposed larvae; black line-negative controls, healthy plant as well as NTC—no template control.

The absolute quantification, based on 1a and 2a viral targets, was performed using a ddPCR reaction. EvaGreen ddPCR results showed that the accumulation of the 1a gene is higher than the 2a gene. The EvaGreen ddPCR showed positive droplets for tested plants detecting 20-554 copies of 1 a gene in the $20 \mu \mathrm{L}$ reaction mixture that corresponds to 16-443 copies per $1 \mathrm{mg}$ plant tissue. The absolute quantity of 2a gene was a bit lower, indicating 20-190 copies in $20 \mu \mathrm{L}$ of PCR volume, which corresponds to 16-152 copies/1 mg plant tissue in three out of five tested plants, and in the two remaining plants $(\mathrm{Nb} 1$ and $\mathrm{Nb5}$ ), we indicated only $\sim 3-5$ copies $/ 1 \mu \mathrm{L}$ of reaction, the equivalent of $2-4$ copies per $1 \mathrm{mg}$ of plant tissue (Figure 6). 


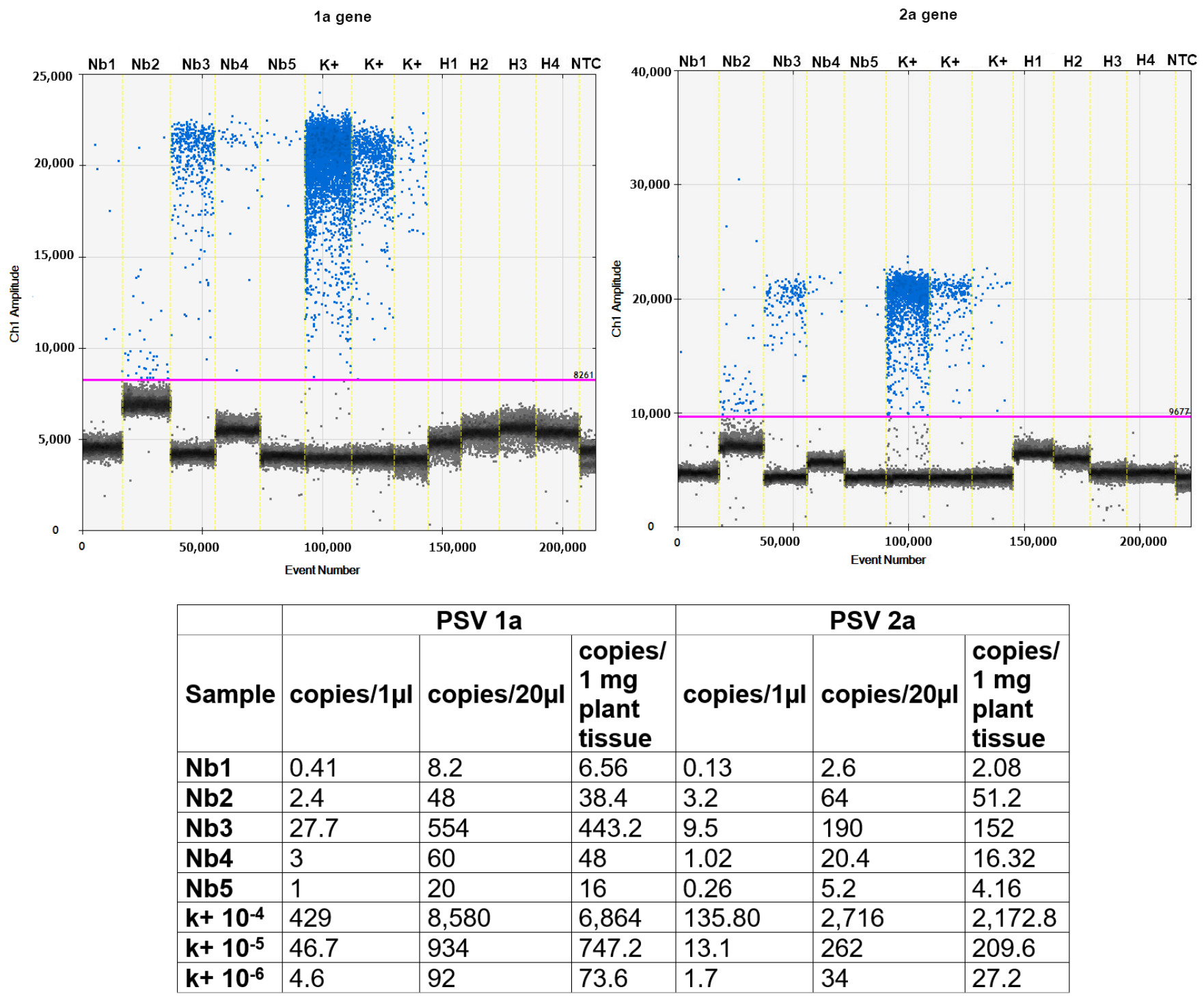

Figure 6. The ddPCR detection of viral 1a and 2a genes in N. benthamiana plants after inoculation with PSV-exposed larvae. (Upper) 1-D plot diagrams present differences in amplitudes of fluorescence signals between positive and negative droplets for 1a (left) and 2a (right). The black droplets represent negative droplets with no templates, and blue represent positive droplets containing amplified templates; pink line: threshold separating negative from positive droplets. Nb1-Nb5 samples of tested plants inoculated with the viruliferous insect; $\mathrm{H} 1-\mathrm{H} 4$ healthy plants of $N$. benthamiana; $\mathrm{K}(+)$ positive controls cDNA from PSV infected plants (10-fold diluted, $\left.1 \times 10^{-4}, 10^{-5}, 10^{-6}\right)$; NTC - no template control. (Below) The EvaGreen ddPCR absolute quantification of copies number of PSV 1a and 2a genes per $1 \mu \mathrm{L}$ of ddPCR reaction mixture, in $20 \mu \mathrm{L}$ of the reaction mixture and the equivalent of copy number of viral RNA1 and RNA2 per 1 mg of plant tissue.

\subsection{Detection of PSV by Western Blotting}

To finally confirm that PSV was transmitted by viruliferous larvae of $B$. impatiens, the PSV specific antisera was used for immunodetection. Western blot on crude plants extracts from N. benthamiana plants inoculated with PSV-infected larvae confirmed the presence of PSV coat protein. We detected the CP (ca. $24 \mathrm{kDa}$ ) and its dimers in plants inoculated with B. impatiens PSV-exposed larvae, the same signal was detected in the positive controls: $N$. benthamiana plants mechanically inoculated with PSV, and in purified virions preparations. No signal was detected for healthy, untreated N. benthamiana plants (Figure 7). 


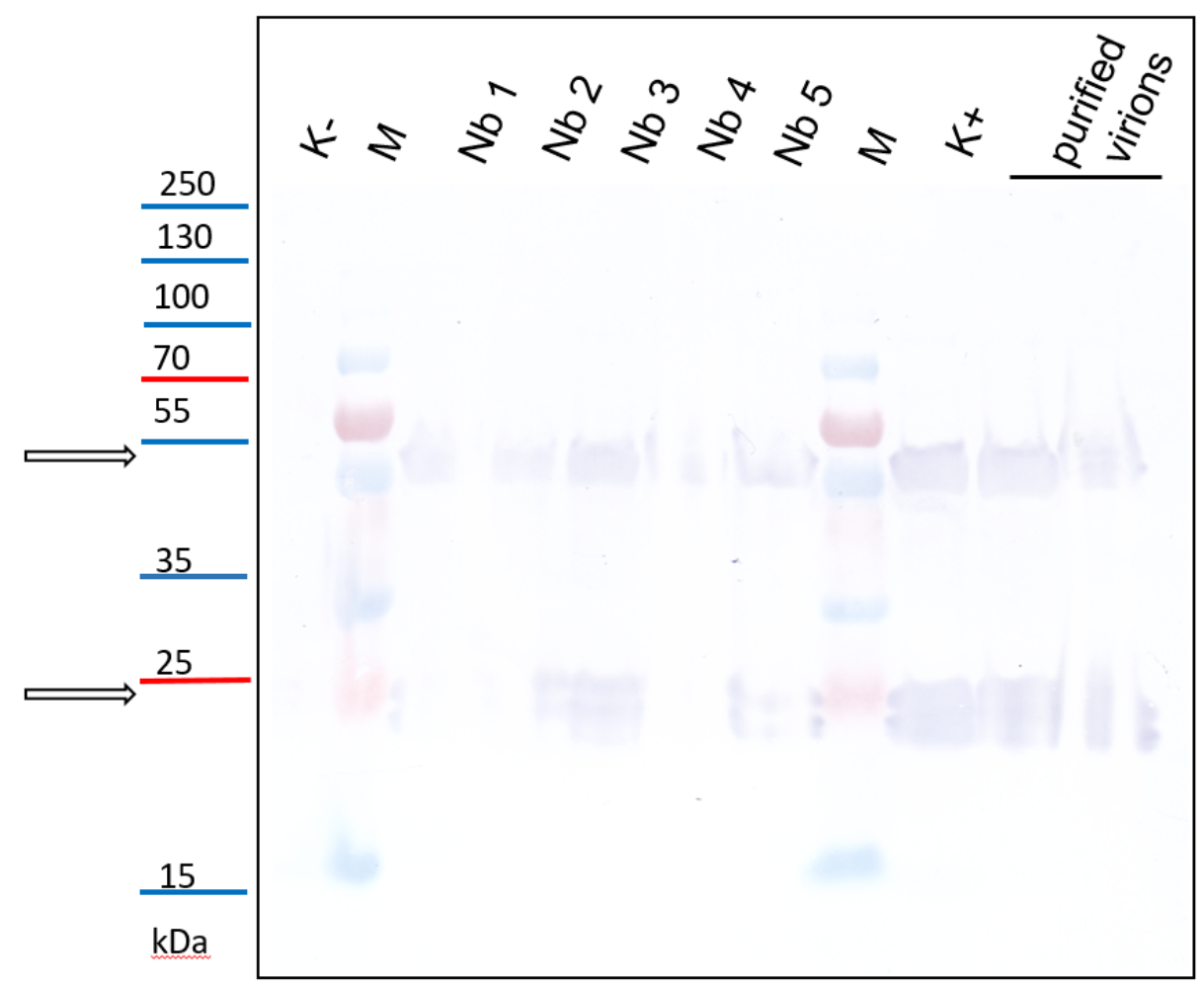

Figure 7. Detection of PSV coat protein in N. benthamiana plants inoculated with virus-exposed larvae of $B$. impatiens by western blotting. $\mathrm{K}-$ - healthy plant, untreated $N$. benthamiana; samples $\mathrm{Nb} 1-5: \mathrm{N}$. benthamiana plants inoculated with $B$. impatiens larvae; M-protein marker PageRuler ${ }^{\mathrm{TM}}$ Prestained Protein Ladder Plus (Thermo Scientific, Lenexa, KS, USA), K+- positive control, PSV-inoculated plant; purified virions: as positive controls protein extracts from native virus preparations were also used. The PSV coat protein and its dimers are indicated by black arrows.

\section{Discussion}

The primary focus of this study was to determine the ability of B. impatiens larvae, in laboratory trials, to acquire and then to vector PSV. Our previous observations, performed in the controlled experimental conditions, indicated the accidental contamination with PSV of previously healthy plants that were grown in the same glasshouse cabin with virus-infected $N$. benthamiana. Thus, we have undertaken to analyse the potential involvement of Bradysia spp., which was the only factor present in greenhouse soil that could have contributed to the virus transmission. The RT-PCR analyses carried out on RNAs isolated from samples of larvae, pupae, and adults of fungus gnat, collected from soil pots, unexpectedly confirmed the presence of PSV genomic RNAs in all insect stages. These data prompted us to explore this observation.

Indeed, the analyses performed in this study, confirmed our preliminary results. We confirmed the ability of virus acquisition by the larval stage of $B$. impatiens and its persistence within the insect body during its development. The observation suggests that the virus persists transstadially. In this respect, these data are in agreement with the results of the experiments on fungi vectoring capacity of B. impatiens [15]. It is worth adding that, when we started work on this issue, we also detected the presence of PSV RNA in the second generation (F2) of $B$. impatiens, namely, in freshly laid eggs from adult females of $B$. impatiens (whose larval stadium of F1 was exposed to PSV) as well as in the specimens of larvae from the second generation (F2) hatched from these eggs (Supplementary Figure S1). However, we did not obtain repeatability, which may have resulted from the low level of virus RNA accumulation or possibly from the fact that PSV was not detectable in all laid eggs. That is why we cannot conclude that the virus persists transgenerationally 
in B. impatiens. However, these results showed that PSV-infested larvae developed into PSV-infested pupae and then into PSV-infested adults.

In the light of these data, a further question that arises is about the mode of virus transmission in the fungus gnat's body. Thus far, cucumoviruses have been known to be transmitted by aphids (subfamily Aphidinae) in a non-persistent manner. Over 80 species of aphids have been identified to vector CMV [24,25], whereas PSV is known to be transmitted by Aphis craccivora, A. solanella, A. spiraecola, Myzus persicae, and Liaphis erysimi $[26,27]$. Currently, many authors focus on clarifying the cucumovirus-aphid-plant interactions [24,28-30]. Noteworthy, Kameya-Iwaki et al. have proven that PSV and CMV might be transmitted by M. persicae in a non-persistent but also in a semi-persistent manner, depending on the plant species used for the assay [25,31].

Viruses vectored by insects are divided into two categories: non-circulative (NC) and circulative viruses (CVs). In the first category, the viral particles attach to the cuticle of the insect vector without circulation in the insect body [32]. The NC viruses are divided into subcategories, transmitted in a non-persistent and semi-persistent manner, depending on the duration of virus retention in the insect's body. Non-persistent virus transmission is characterized by very short acquisition and inoculation times of seconds to minutes. In the semi-persistent transmission, the acquisition can occur within minutes, but the transmission efficiency increases with prolonged insect feeding. Moreover, the second distinguishing feature is the retention period of hours to days [33]. In the second group, $\mathrm{CVs}$ need to circulate in the insect tissue before transmission to healthy plants. In some cases, these viruses can also replicate in the vector's body [32,34]. The quantitative analyses of viral RNAs in developmental stages of fungus gnat showed that the amount of viral RNA1 encoding 1a ORF in the pupa stage was in a few cases higher than in the larvae that acquired viral particles. The obtained data suggested a far-reaching hypothesis that PSV may circulate or even replicate in fungus gnats tissues in contrast to the abovementioned transmission in the aphid. On the other hand, the differences in virus RNA accumulation are an individual matter of specimens, and the larvae (from which the analysed pupae developed) previously acquired much more virus compared to the others. However, only further experiments will shed light on the replication of this virus in different developmental stages of $B$. impatiens.

On the basis of the available literature, Bradysia species are known to be vectoring soilborne pathogens [21]. In 1990 Gardiner et al. showed that the larval stage of B. impatiens might act as an important vector for Pythium spp. [21]. However, there are no literature data on the role of Bradysia spp. in virus spreading. The transmission assay performed in this study has shown that $B$. impatiens larvae exposed to PSV are able to transmit the virus to a healthy plant. In 2010, Braun et al. have reported transstadial transmission of Pythium and proved the lack of $B$. impatiens adults vectoring ability [15]. The vectoring capacity of adult stages has been poorly studied. Nevertheless, a few reports have indicated the role of adults of $B$. impatiens in pathogen transmission [12]. Kapongo and co-workers in 2020 showed that not only larva, but also adults of B. impatiens might be a vector of Fusarium oxysporum and Pythium aphanidermatum [35]. In this study, we have not confirmed the ability of an adult insect to transmit the virus to healthy plants. On the basis of the obtained data, the virus acquired in the larval stage persists transstadially, which is also in agreement with the previous report published by Braun and co-workers [15]. Hence, the most likely possibility is that a virus is transmitted by the larva in the second generation (F2). As mentioned above, PSV was detected in the eggs and larvae of the F2 generation, but only in one experiment. In general, we suppose that virus might be carried on a very low level in F2 eggs or might be present only in some of them, or it may not always be transferred to the next generation. Hence, this issue needs further experiments that will include a larger number of samples, to draw reliable conclusions.

In the molecular experiments complemented with biological test on PSV-exposed larvae and healthy plants of $N$. benthamiana, we have shown that B. impatiens larvae have the vectoring capacity. However, after the inoculation access period, the level of 
the viral RNA accumulation in plant tissues, in almost all cases, was rather low. Visual observation of plants inoculated by viruliferous $B$. impatiens revealed no characteristic symptoms of PSV infection. The typical symptoms of PSV infection on N. benthamiana are stunting, leaves malformation, and chlorosis. However, in some cases, the symptoms may be attenuated, depending on various conditions, among other temperature $[22,36]$. Herein, the symptomless infection might result from a small number of virus particles or low transmission efficiency caused by a small number of insect specimens used in these experiments. However, using the Western blotting approach, we have confirmed the presence of viral coat protein, which proves that the genomic strands of PSV, detected in the plants exposed to viruliferous larvae of $B$. impatiens, are infectious.

Thus, on the basis of the above-described findings, B. impatiens role as a plant virus vector, or a reservoir of this pathogen, should be taken into account. The obtained data help to better understand the biology of B. impatiens and its role in plant pathogen spreading.

Supplementary Materials: The following are available online at https:/ / www.mdpi.com/article/10 .3390/cells10061546/s1, Figure S1: RT-PCR detection of PSV 1a gene of chosen developmental stages of Bradysia impatiens.

Author Contributions: Conceptualization, M.B., P.F., and A.O.-S.; methodology, M.B., P.F., and A.O.-S.; formal analysis, M.B., P.F., and A.O.-S.; investigation, M.B. and P.F.; resources, A.O.-S.; data curation, M.B. and P.F.; writing —original draft preparation, M.B. and A.O.-S.; writing-review and editing, M.B., P.F., and A.O.-S.; supervision, A.O.-S.; project administration, A.O.-S.; funding acquisition, A.O.-S. All authors have read and agreed to the published version of the manuscript.

Funding: This work was supported by the Polish Ministry of Science and Higher Education, statutory activity project: BIOTECH01.

Institutional Review Board Statement: Not applicable.

Informed Consent Statement: Not applicable.

Data Availability Statement: All data are provided in the manuscript and in the GenBank database.

Acknowledgments: We wish to thank Marek Tomalak from the Department of Biological Pest Control and Organic Agriculture, IPP-NRI (Poznań, Poland) for his valuable comments. We thank also Irena Nowacka from the Department of Entomology and Agricultural Pests, IPP-NRI (Poznań, Poland) for providing the population of Bradysia spp.

Conflicts of Interest: The authors declare no conflict of interest.

\section{References}

1. Katumanyane, A.; Ferreira, T.; Malan, A.P. A Review of Bradysia spp. (Diptera: Sciaridae) as Pests in Nursery and Glasshouse Crops, with Special Reference to Biological Control Using Entomopathogenic Nematodes. Afr. Entomol. 2018, 26, 1-13. [CrossRef]

2. Menzel, F.; Smith, J.E.; Colauto, N.B. Bradysia difformis Frey and Bradysia ocellaris (Comstock): Two additional neotropical species of black fungus gnats (Diptera: Sciaridae) of economic importance: A redescription and review. Ann. Entomol. Soc. Am. 2003, 96, 448-457. [CrossRef]

3. Rebora, M.; Salerno, G.; Piersanti, S.; Gorb, E.; Gorb, S. Entrapment of Bradysia paupera (Diptera: Sciaridae) by Phaseolus vulgaris (Fabaceae) plant leaf. Arthropod-Plant Interact. 2020, 14, 499-509. [CrossRef]

4. Cloyd, R.A. Ecology of fungus gnats (Bradysia spp.) in greenhouse production systems associated with disease-interactions and alternative management strategies. Insects 2015, 6, 325-332. [CrossRef] [PubMed]

5. Wilkinson, J.D.; Daugherty, D.M. The biology and immature stages of Bradysia impatiens (Diptera: Sciaridae). Ann. Entomol. Soc. Am. 1970, 63, 656-660. [CrossRef]

6. Woelke, J.B.; Pham, K.; Humala, A.E. New species of Stenomacrus (Hymenoptera: Ichneumonidae: Orthocentrinae) reared from Bradysia impatiens (Diptera: Sciaridae) in The Netherlands. J. Nat. Hist. 2020, 54, 1603-1616. [CrossRef]

7. Hall, R.D.; Gerhardt, R.R. Medical and Veterinary Entomology, 2nd ed.; Mullen, G.R., Durden, L.A., Eds.; Academic Press: Cambridge, MA, USA, 2009.

8. Chabannes, M.; Hatt, G.; Thébaud, G.; Bedford, I.D.; Lamb, C. Establishment of an in vitro sciarid fly larvae assay to study plant resistance. Ann. Appl. Biol. 2009, 155, 293-296. [CrossRef]

9. James, R.L.; Dumroese, R.K.; Wenny, D.L. Botrytis cinerea carried by adult fungus gnats (Diptera: Sciaridae) in container nurseries. Tree Plant Notes 1995, 46, 48-53. 
10. Jagdale, G.B.; Casey, M.L.; Cañas, L.; Grewal, P.S. Effect of entomopathogenic nematode species, split application and potting medium on the control of the fungus gnat, Bradysia difformis (Diptera: Sciaridae), in the greenhouse at alternating cold and warm temperatures. Biol. Control 2007, 43, 23-30. [CrossRef]

11. Leath, K.T.; Newton, R.C. Interaction of a fungus gnat Bradysia sp (Sciaridae) with Fusaium spp on alfaalfa and red clover. Phytopathology 1969, 59, 257.

12. Kalb, D.W. Dispersal of Verticillium albo-atrum by the Fungus Gnat (Bradysia impatiens). Plant Dis. 1986, 70, 752. [CrossRef]

13. Jarvis, W.R.; Shipp, J.L.; Gardiner, R.B. Transmission of Pythium aphanidermatum to greenhouse cucumber by the fungus gnat Bradysia impatiens (Diptera: Sciaridae). Ann. Appl. Biol. 1993, 122, 23-29. [CrossRef]

14. Edwardson, J.R.; Christie, R.G. CRC Handbook of Viruses Infecting Legumes; CRC Press: Boca Raton, FL, USA, 1991.

15. Braun, S.E.; Castrillo, L.A.; Sanderson, J.P.; Daughtrey, M.L.; Wraight, S.P.; Braun, S.E. Transstadial Transmission of Pythium in Bradysia impatiens and Lack of Adult Vectoring Capacity. Phytopathology 2010, 100, 1307. [CrossRef]

16. Park, J.M.; You, Y.H.; Park, J.H.; Kim, H.H.; Ghim, S.Y.; Back, C.G. Cutaneous microflora from geographically isolated groups of bradysia agrestis, an insect vector of diverse plant pathogens. Mycobiology 2017, 45, 160-171. [CrossRef]

17. Obrepalska-Steplowska, A.; Nowaczyk, K.; Budziszewska, M.; Czerwoniec, A.; Pospieszny, H. The sequence and model structure analysis of three Polish peanut stunt virus strains. Virus Genes 2008, 36, 221-229. [CrossRef] [PubMed]

18. Obrępalska-Stęplowska, A.; Budziszewska, M.; Wieczorek, P.; Czerwoniec, A. Analysis of two strains of Peanut stunt virus: SatRNA-associated and satRNA free. Virus Genes 2012, 44, 513-521. [CrossRef]

19. Obrepalska-Steplowska, A.; Budziszewska, M.; Pospieszny, H. Complete nucleotide sequence of a Polish strain of Peanut stunt virus (PSV-P) that is related to but not a typical member of subgroup I. Acta Biochim. Pol. 2008, 55, 731-739. [CrossRef]

20. Fereres, A.; Raccah, B. Plant Virus Transmission by Insects. eLS 2015, 1-12. [CrossRef]

21. Gardiner, R.B.; Jarvis, W.R.; Shipp, J.L. Ingestion of Pythium spp. by larvae of the fungus gnat Bradysia impatiens (Diptera: Sciaridae). Ann. Appl. Biol. 1990, 116, 205-212. [CrossRef]

22. Obrepalska-Steplowska, A.; Renaut, J.; Planchon, S.; Przybylska, A.; Wieczorek, P.; Barylski, J.; Palukaitis, P. Effect of temperature on the pathogenesis, accumulation of viral and satellite RNAs and on plant proteome in peanut stunt virus and satellite RNA-infected plants. Front. Plant Sci. 2015, 6, 903. [CrossRef]

23. Vilkamaa, P. Checklist of the family Sciaridae (Diptera) of Finland. Zookeys 2014, 441, 151-164. [CrossRef]

24. Tungadi, T.; Donnelly, R.; Qing, L.; Iqbal, J.; Murphy, A.M.; Pate, A.E.; Cunniffe, N.J.; Carr, J.P. Cucumber mosaic virus $2 b$ proteins inhibit virus-induced aphid resistance in tobacco. Mol. Plant Pathol. 2020, 21, 250-257. [CrossRef]

25. Kameya-Iwaki, M.; Murakami, K.; Ito, S.; Hanada, K.; Tanaka, S. Semipersistency of Myzus persicae transmission of cucumoviruses systemically infecting leguminous plants. J. Gen. Plant Pathol. 2000, 66, 64-67. [CrossRef]

26. Hebert, T.T. Epidemiology of the peanut stunt virus in North Carolina. Phytopathology 1967, 57, 461.

27. El Sadiq, E.O.; Ahmed, A.H. Comparative studies on aphid transmission of the Sudanese strain of peanut stunt virus. J. Phytopathol. 1986, 115, 160-164. [CrossRef]

28. Liang, Y.; Gao, X.-W. The cuticle protein gene MPCP4 of Myzus persicae (Homoptera: Aphididae) plays a critical role in cucumber mosaic virus acquisition. J. Econ. Entomol. 2017, 110, 848-853. [CrossRef]

29. Krenz, B.; Bronikowski, A.; Lu, X.; Ziebell, H.; Thompson, J.R.; Perry, K.L. Visual monitoring of Cucumber mosaic virus infection in Nicotiana benthamiana following transmission by the aphid vector Myzus persicae. J. Gen. Virol. 2015, 96, 2904-2912 [CrossRef]

30. Wamonje, F.O.; Donnelly, R.; Tungadi, T.D.; Murphy, A.M.; Pate, A.E.; Woodcock, C.; Caulfield, J.; Mutuku, J.M.; Bruce, T.J.A.; Gilligan, C.A.; et al. Different Plant Viruses Induce Changes in Feeding Behavior of Specialist and Generalist Aphids on Common Bean That Are Likely to Enhance Virus Transmission. Front. Plant Sci. 2020, 10, 1811. [CrossRef]

31. Kameya-Iwaki, M.; Shigeyoshi, M.; Ito, S.; Tanaka, S. Effects of susceptibility of test plants on modes of Cucumovirus transmission by Myzus persicae. J. Gen. Plant Pathol. 2001, 67, 69-72. [CrossRef]

32. Garzo, E.; Moreno, A.; Plaza, M.; Fereres, A. Feeding Behavior and Virus-transmission Ability of Insect Vectors Exposed to Systemic Insecticides. Plants 2020, 9, 895. [CrossRef]

33. Ng, J.C.K.; Perry, K.L. Transmission of plant viruses by aphid vectors. Mol. Plant Pathol. 2004, 5, 505-511. [CrossRef] [PubMed]

34. Yadav, D.; Rana, R. Transmission of plant virus through arthropod vector. J. Entomol. Zool. Stud. 2020, 8, 1934-1939.

35. Kapongo, J.-P.; Kevan, P.G.; Shipp, L.; Taki, H. Making a Pest Beneficial: Fungus Gnats [Bradysia impatiens (Diptera: Sciaridea)] as Potential Vectors of Microbial Control Agents to Suppress Pathogens they Also Spread. In Entomovectoring for Precision Biocontrol and Enhanced Pollination of Crops; Springer: Berlin/Heidelberg, Germany, 2020; pp. 239-250.

36. Obrepalska-Steplowska, A.; Wieczorek, P.; Budziszewska, M.; Jeszke, A.; Renaut, J. How can plant virus satellite RNAs alter the effects of plant virus infection? A study of the changes in the Nicotiana benthamiana proteome after infection by Peanut stunt virus in the presence or absence of its satellite RNA. Proteomics 2013, 13, 2162-2175. [CrossRef] [PubMed] 